\title{
PARASITOLOGY
}

\author{
A SUPPLEMENT TO THE \\ JOURNAL OF HYGIENE
}

The Journal will be issued at intervals determined by the material received by the Editors. A volume containing about 400 to 500 pages, with plates and figures, will be issued annually. The price to subscribers, payable in advance, will be $£ \mathrm{I}$. I $s$. net per volume (post free). Subscribers to the Journal of Hygiene may obtain Parasitology at the reduced price of $\mathrm{I}_{5}$ s. net per volume.

\author{
CAMBRIDGE UNIVERSITY PRESS WAREHOUSE, \\ C. F. Clay, Manager. \\ Ilonoon: FETTER LANE, E.C. \\ AND H. K. LEWIS, GOWER STREET, W.C. \\ Ėinturgy: 100, PRINCES STREET. \\ Lriqzig: F. A. BROCKHAUS. \\ Berlin: A. ASHER AND CO. \\ \#2Ew Gork: G. P. PUTNAM'S SONS. \\ lBambay and Calcutta: MACMILLAN AND CO., LrD.
}

\section{FORM OF ORDER}

\author{
(Date)
}

Please enter my name as a subscriber for cop of PARASITOLOGY at the subscription price of Twenty-one Shillings per volume. The amount of the subscription for Vol. I accompanies this order.

\author{
(Name) \\ (Address)
}

To $M$

(Bookseller)

P. T. O. 


\section{TICKS \\ A Monograph of the Ixodoidea}

\section{Part I. The Argasidae}

\section{Section I}

Dealing with the Classification of the Argasidae-The differences between Argasidae and Ixodidae-the family characters of the Argasidae (Synonymy and Literature)-the genera Argas and Ornithodoros, their structure and classification, with synonymy and literature relating to all the well established, doubtful and condemned species.

\section{SECTION II}

Dealing with the general biology of the Argasidae, the effects of their bites, their relation to the spread of disease.

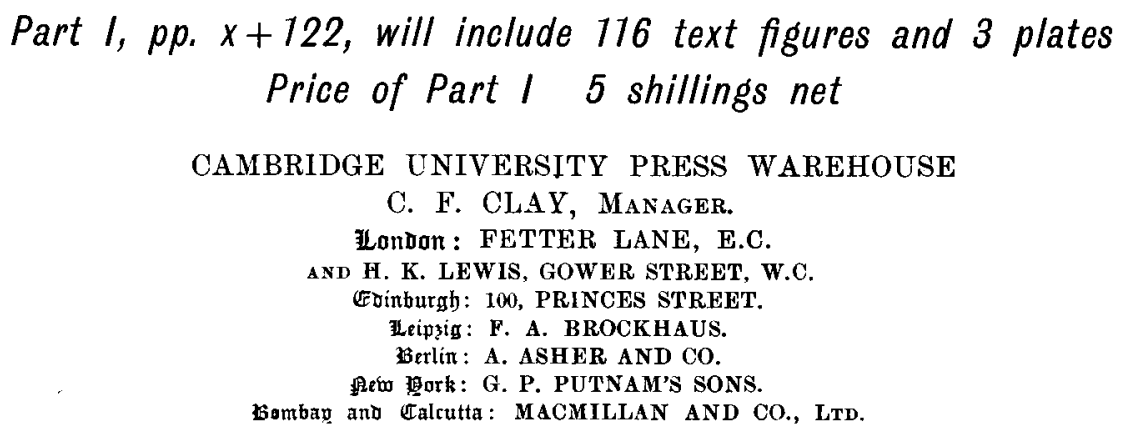

\section{FORM OF ORDER}

(Date)

Pleose send me cop ......... of Ticks, A Monograph of the Ixodoidea, Part I, at Five Shillings net.

(Name)

(Address)

To $M$ (Bookseller) 


\title{
Important for Economic Biologists, Zoologists
} and Medical Men

PUBLISHED BY THE UNIVERSITY PRESS, CAMBRIDGE

\section{TICKS}

A Monograph of the Ixodoidea

\author{
By \\ GEORGE H. F. NUTTALL \\ M.A., M.D., Рн.D., Sc.D., F.R.S. \\ Fellow of Magdalene College, \\ Quick Professor of Biology in the University of Cambridge, \\ CECIL WARBURTON \\ M.A., F.Z.S. \\ Christ's College, Zoologist to the Royal Agricultural Society,
W. F. COOPER
and
L. E. ROBINSON
B.A., F.Z.S., F.I.S.
A.R.C.Sc. (London).

The discovery of the economic importance of ticks as carriers of disease to man and domesticated animals has led to a vast increase of our knowledge of this group. No existing work in any language attempts to deal with the subject in a comprehensive manner, and the student is confronted with a very extensive and widely scattered literature from which he derives an impression of hopeless confusion. There is, therefore, urgent need for a work of the nature here attempted.

The book will deal with the Classification, Structure and Biology of Ticks, the study of the group having occupied the authors for several years. Practically all that has been published on the subject has received adequate consideration. The parts on Classification have entailed much labour since it was found necessary to revise a large amount of the work which has been done by others. The book will be very fully illustrated by numerous text figures and plates, the majority of which are original; the remainder have been reproduced from the best sources.

The book will be issued in about four parts, which will be complete in themselves but are designed to form a volume of about 500 pages when all the parts have been published. Each part will be issued in a stiff paper cover and will include a bibliography printed on one side of thin paper so that the references can be conveniently cut out and gummed on index cards. $\boldsymbol{A}$ complete bibliography, including all the publications cited in each part, will conclude the volume.

P. T. 0 . 
Quarterly Journal of Medicine. Edited by William OsLeR, J. Rose bradford, R. Hurchison, A. E. Garrod, H. D. Rolleston, and W. Hale Wirte. Vol. I, Nos. 1 to 5. 8s. 6d. net each. Annual Subseription, 25s. per annum.

English Medicine in Anglo-Saxon Times: the FitzPatrick Lectures for 1903. By J. F. PAyne. 8vo, with 23 illustrations. 8s. $6 d$. net.

The Study of Medicine in the British Isles: the FitzPatrick Lectures for 1905-6. By Norman Moore. 8vo, with 13 Collotype plates. 10s. $6 d$. net.

The Construction of Healthy Dwellings. By Sir D. Galton. Second edition. 8vo. 10s. 6d.

Healthy Hospitals. By the same, with illustrations. 8vo. 10 s. $6 d$.

Two Oxford Physiologists (Lower and Mayow). By Francis Gotch. 8vo. 1s. net.

De Bary's Lectures on Bacteria. Second edition. Translated by H. E. F. Garnsey, revised by I. Bayley Balfour. Crown 8 vo, cloth, $5 s$. net.

Fischer's Bacteria, translated by A. Coppen Jones. Cloth, 7s. $6 d$. net.

\section{Oxford Medical Publications.}

A Complete Catalogue can be obtained from Mr Frowde.

LONDON: HENRY FROWDE, OXFORD UNIVERSITY PRESS, AMEN CORNER, E.C.

\section{PARASITOLOGY}

\section{A SUPPLEMENT TO THE JOURNAL OF HYGIENE}

Edited by GEORGE H. F. NUTTALL, F.R.S., Quick Professor of Biology in the University of Cambridge, and A. E. SHIPLEY, F.R.S., University Lecturer in the Advanced Morphology of the Invertebrate.

When the dournal of Hygiene was founded it was announced that papers on Parasitology "in relation to hygiene and preventive medicine" would he published in its pages. It has however been felt for some time that the Journal was becoming unduly burdened with papers dealing with the anatomy of mosquitoes, fleas, protozoa and other parasites-of great importance in themselves-but having only an indirect relation to hygiene and preventive medicine.

The remarkable development of parasitology in recent years, and the increase in our knowledge of the part played by parasites in human and animal diseases, demand a means of publication, in the English language, of original papers dealing with the subject in its widest sense. It is proposed in future to relegate all such papers to Parasitology.

It is hoped that this publication will appeal not only to medical men at home and abroad, but to veterinarians, zoologists and agriculturalists.

Parasitology, though a supplement to the Journal of Hygiene, will be issued in the form of a separate yearly volume of four to five hundred pages. The parts will be issued when sufficient material has accumulated. The first two parts are now ready. The subscription price is 21 . $1 s$. per volume (post-free), payable in advance; single numbers $7 \mathrm{~s}$. net. Subscribers to the Journal






\section{PAUL ALTMANN,}

47, Luisen-Strasse,

Ecke Schumann-Strasse, BERLIN. N.W.. GERMANY,

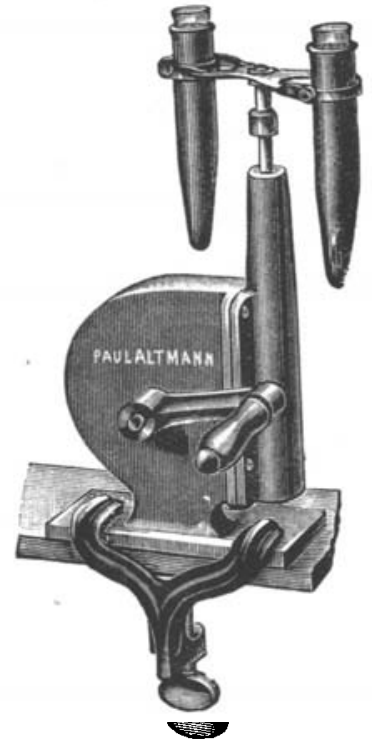

Price : 22 Marks.

Manufacturer of all kind of apparatus and appliance! for Chemistry, Bacteriology Microscopy and Hygiene.

All Goods manufactured ir our own workshops.

COMPLETE OUTFITS of Bacteriological-Microsco. pical and Hygieno-Chemical Laboratories.

\section{SPECIALITY :}

Disinfecting and Sterilising Apparatus.

Thermostats, adjustable for a Constant Temperature. Autoclaves, Centrifugals. Apparatus for Clinical Laboratories, etc., etc.

Full Illustrated Price Lists on Application.

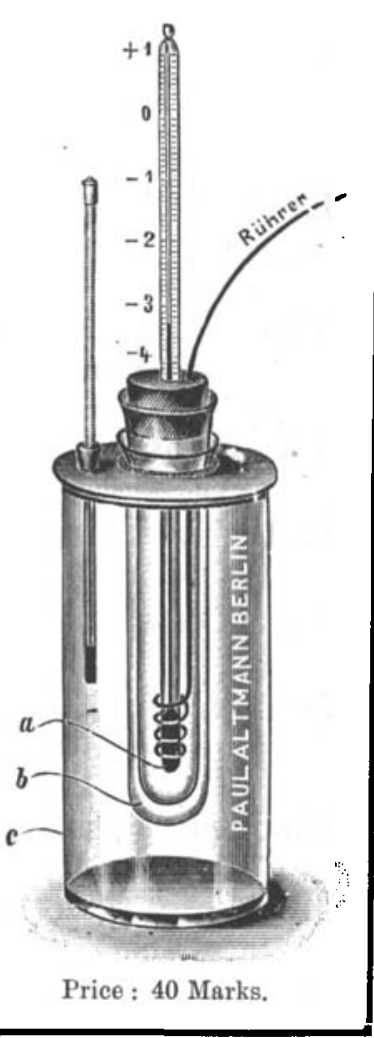

\section{SCIENTIFIC APPARATUS}

\section{JOHN J. GRIFFIN \& SONS, Ltd., KINGSWAY, LONDON, W.C.}

Makers to the Admiralty, War Office, India, Colonial and Foreign Governments.

Every facility for making Apparatus to Original Specifications. ENQUIRIES SOLICITED.

SOLE DEPÔT FOR KAHLBAUM'S CHEMICALS.

Price-list post-free on application.

\section{CAMBRIDGE GEOGRAPHICAL SERIES.}

General Editor: F. H. H. Guillemard, M.D., FORMERLY LECTURER IN GEOGRAPHY IN THE UNIVERSITY OF CAMBRIDGE.

\section{THE GEOGRAPHY OF DISEASE}

By FRANK G. ClEmoW, M.D. Edin., D.P.H. Camb.,

British Delegate to the Ottoman Board of Health, Physician to H.M. Embassy at Constantinople.

Crown 8vo. Cloth. 12 Maps and Charts. Price 15 s.

LANCET. - “Dr Clemow's writings are well known to all epidemiologists and his intimate knowledge of the Russian language bas enabled him to study the disease and death records of the vast population of that great European and Asiatic country in a manner whioh is impossible to most writers.... In a preface upon the Geography of Disease and the factors which determine it we find discussed in a fascinating fashion the complex nature of the problem." 


\section{CAMBRIDGE UNIVERSITY PRESS}

Royal 8vo. With 4 Portraits and 16 Plates. Price 25s, net.

\section{THE BACTERIOLOGY OF DIPHTHERIA}

including Sections on the History, Epidemiology and Pathology of the Disease, the Mortality caused by it, the Toxins and Antitoxins and the Serum Disease. By F. Loefrlaer, M.D., LL.D., Arthur Newshonge, M.D., F.R.C.P., F. B. MaLLoRY, M.A., M.D., G. S. Graнам-Sмттн, M.A., M.D., D.P.H., George Dean, M.D., Whuiam H. Park, M.D. and Charles F. Boldodan, M.D.

\section{Edited by}

G. H. F. NUTTALL, M.D., Ph.D., Sc.D., F.R.S., Quick Professor of Biology in the University of Cambridge,

AND G. S. GRAHAM-SMTTH, M.A., M.D., University Lecturer in Hygiene, Cambridge.

"A complete monograph upon diphtheris, written by those who are able to speak with the greatest authority upon the subjects with which they have been entrusted by the editors.... The mere enumeration of the writers is a sufficient guarantee of the excellence of the work, and of the anthority which it earries; whilst the articles are written in elear and good English, free, for the most part, from the technical terms which make many treatises on baeteriology difficult and unprofitable to read. The articles are well harmonized, and the teaching in regard to difficult and debatable points is marked by moderation and common sense."

Athenaeum, April 8, 1908.

Royal 8vo. Buckram. pp. xvi+592, Price 18s. net.

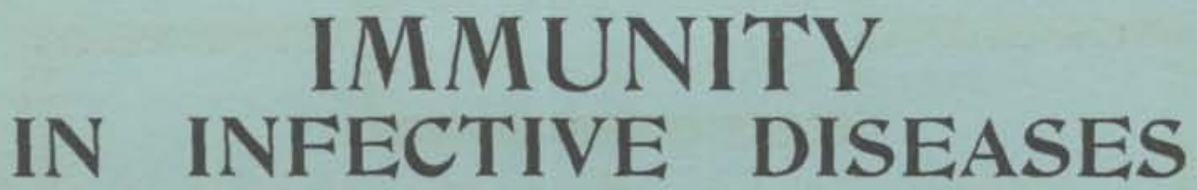

Bx ÉLIE METCHNIKOFF

Foreign Member of the Royal Society of London, Professor at the Pasteur Institute, Paris

TRANSLATED FROM THE FRENCH

By FRANCIS G. BINNIE

of the Pathological Department, University of Cambridge

With 45 figures in the text.

\section{CONTENTS.}

Chap. I. Immunity in unicellulur organisms,-II. Immunity in multicellular plants.III. Preliminary remarks on immunity in the animal kingdom.-IV. Resorption of the formed elements.- $\nabla$. Resorption of albuminoid fluids.-VI. Natural immunity against pathogenic miero-organisms,-VII. The mechanism of natural immunity against micro-organisms, VIII. Survey of the facts bearing on sequired immunity against micro-organism8.-IX. The meohanism of aequired immunity against micro-organisms. - X. Rapid and temporary immunity against mioro-organisms, conferred by speeific and normal serums, or by other substances, or by miero-organisms other than those against which it is desired to protect an animal. - XI. Natural immunity against toxins, - XII. Artifieial immunity against toxins, - XIII. Immunity of the skin and mucous membranes, - XIV. Immunity acquired by nstural means. $-\mathrm{XV}$. Protective vaccinations,-XVI. Historioal sketch of onr knowledge of immunity.-XVII. Summary.

LANCET. - "That a transiation of Professor Metchnikoff's valuable and fascinating book on Immunity should be made was most desirable, we might almost say indispensable, and those who may have been deterred from studying the original owing to its being in a foreign tongue will be grateful to Mr Binnie for the work which he has done.... The book is most interesting reading. ... Study of it is indispensable to all who are specially interested in the subjeot of Immunity." 


\section{(All rights reserved.)}

Boycott, A. E. and Damant, G. C. C. Experiments on the Influence of Fatness on Susceptibility to Caisson Disease.

Currie, J. R. Abnormal Reactions to Horse Serum in the Serum Treatment of Cerebrospinal Fever. (Three Figures.)

Duck Ering, G. Elmhirst. The Cause of Lead Poisoning in the Tinning of Metals. (One Figure.) . . . .

Ruffer, Maro Armand and Willmore, J. Graham. The Drinking Water of Steamships . . . . . . 504

Green, Alan B. Some Experiments on Immunity against Vaccinia in Animals

Green, Alun B. The Influence of Temperature, and some other Physical Conditions, on Calf Vaccine. (One Figure.)

Watson, Herbert Edmeston. A Note on the Variation of the

Rate of Disinfection with Change in the Concentration of the Disinfectant. (One Figure.).

Wuson, W. James, Bacteriological Observations on Colon Bacilli infecting the Urinary Tract, with special remarks on certain Colon Bacilli of the "Anaerogenes" class

Abstracts of Official Publications, ete. The Campaign against Ankylostomiasis in Porto Rico

Publications RECEIVED

The Journal of Hygiene is issued quarterly. A volume containing about 500 pages, with plates and figures, is issued annually.

Volumes I, II, and III (1901-3) complete. In Four Parts, paper covers, 158. net per volume. Bound in buckram, 18s. 6d. net per volume.

Volumes IV, V, VI, and VII (1904-7) complete. Bh Four Parts, paper eovers, 21s. net per volume. Bound in buckram, 25s. net per volume.

Papers for publieation may be sent to Prof. Geo. H. F. Nutrall, F.R.S., 3 Cranmer Road, Cambridge, or to the associate Editors. Other communications should be addressed to the University Press, Cambridge.

Papers forwarded to the Editors for publication are understood to be offered to the Journal of Hygiene alone, unless the contrary is stated.

Contributors receive fifty copies of their papers free. Additional copies may be had at cost price: these should be ordered when the final proof is returned.

The subscription price is $£ 1$. 18. per volume (post-free), payable in advance; single numbers 78 . net. (Plague Numbers, Vol. VI, no. 4, Vol. VII. nos. 3 and 6, and Vol. VIII. no. 2, Price 6s. net each.) Subscriptions may be sent to any Bookseller, or to Mr C. F. CLAY, MANAGER, Cambridge University Press Warehouse, Fetter Lane, London, E.C. 